\title{
PENGARUH JARAK TANAM DAN TEKNIK PEMELIHARAAN TERHADAP PERTUMBUHAN KENUAR (Shorea johorensis Foxw.) DI HUTAN SEMAK BELUKAR WANARISET SAMBOJA, KALIMANTAN TIMUR
}

(The effect of plant spacing and maintenance technique of kenuar (Shorea johorensis Foxw.) at disturbed forest of Wanariset Samboja, East Kalimantan)

Oleh/By:

R. Mulyana Omon dan Burhanuddin Adman

Balai Penelitian Teknologi Perbenihan Samboja

\begin{abstract}
Kenuar (Shorea johorensis Foxw) is one of shorea species that is most potential for forest plantations. This research was to determine the best and most effective maintenance treatment to the growth of kenuar. The research was conducted on a degraded forest within the forest research area of Seed Technology Research Institute, Samboja. The study took place from November 2004 to November 2006. Split plot design was used in which spacing was the main plot and maintenance treatment was the subplot with three replications. The analysis of variance showed that only maintenance treatment significantly affects survival percentage, height growth and diameter growth. Group, spacing and interaction of spacing gave no effect that is statistically significant. The average of survival rate, height growth and diameter growth are $76.34 \%, 62.04$ $\mathrm{cm}$ and $0.81 \mathrm{~cm}$, respectively. BNT test indicated that these averages are associated with the effects of vertical maintenance treatment.
\end{abstract}

Keywords : kenuar (Shorea johorensis Foxw.), degraded forest, spacing, vertical treatment.

\begin{abstract}
ABSTRAK
Pada saat ini, kebutuhan masyarakat terhadap kayu semakin meningkat, hal ini tidak didukung oleh pasokan kayu yang cukup. Sebagai akibatnya tekanan terhadap hutan meningkat yang menyebabkan terjadinya illegal logging. Oleh karena itu, perlu dilakukan pembangunan hutan tanaman dengan jenis-jenis andalan setempat. Salah satu jenis pohon yang dapat dikembangkan dan dikelola adalah kenuar (Shorea johorensis Foxw.), khusus di Kalimantan. Penelitian ini dilakukan untuk mengetahui pengaruh perlakuan pemeliharaan yang paling baik dan efektif terhadap pertumbuhan kenuar. Lokasi penelitian dilaksanakan di hutan penelitian, Balai Penelitian Teknologi Perbenihan Samboja, dimulai pada bulan November 2004 sampai November 2006. Rancangan penelitian yang digunakan adalah split plot dengan jarak tanam sebagai plot utama dan perlakuan pemeliharaan sebagai sub plot dengan tiga ulangan. Analisa data dilakukan dengan analisis varian (ANOVA) dengan Uji-F. Hasil ANOVA menunjukkan kelompok, jarak tanam dan interaksi jarak tanam dan pemelihraan tidak menunjukkan perbedaan yang nyata terhadap persen hidup, pertumbuhan tinggi dan diameter, sedangkan perlakuan pemeliharaan berbeda nyata. Dari hasil uji BNT, pemeliharaan vertikal menunjukkan pengaruh nyata terhadap persen hidup, pertumbuhan tinggi dan diameter dengan rata-rata masing-masing sebesar $76.34 \%, 62.04 \mathrm{~cm}$ and $0.81 \mathrm{~cm}$.
\end{abstract}

Keywords : kenuar (Shorea johorensis Foxw.), hutan belukar, Samboja, Kalimantan Timur 


\section{PENDAHULUAN}

Hutan merupakan salah satu sumberdaya alam yang pada saat ini sedang mengalami tekanan yang cukup besar sebagai akibat dari pemenuhan kebutuhan masyarakat terhadap kayu. Forestry Working Group (2002) menyatakan bahwa kebutuhan bahan baku untuk industri perkayuan di Indonesia menurut data tahun 1999 setiap tahunnya sekitar 63,48 juta $\mathrm{m}^{3} /$ tahun, sedangkan produksi rata-rata kayu bulat lima tahun terakhir ini hanyalah 25 juta $\mathrm{m}^{3} /$ tahun (Direktorat Produksi Hasil Hutan, 2000). Berdasarkan kedua data tersebut dapat terlihat bahwa terdapat kekurangan pasokan kayu untuk industri perkayuan di Indonesia, sehingga konsekuensi dari kesenjangan tersebut adalah semakin maraknya terjadi penebangan liar (illegal logging), terutama di hutan-hutan alam Indonesia. Seperti diketahui bahwa di Kalimantan Timur yang memiliki kawasan hutan seluas 17.875 .100 hektar dan akhir-akhir ini luasan tersebut telah terjadi pengurangan menjadi 13. 616.195 ha atau $25 \%$ areal tersebut telah terdeforestasi (Sutisna, 2006). Bahkan Badan Planologi Kehutanan (2006) memperkirakan laju kerusakan hutan di Kalimantan Timur setiap tahunnya mencapai 376.159 hektar. FWI/GFW (2001) melaporkan bahwa jika laju kerusakan terus berlanjut, maka diperkirakan hutan dataran rendah non rawa di Kalimantan akan lenyap pada tahun 2010.

Salah satu upaya utuk mengatasi ketimpangan pasokan kayu dan kerusakan hutan adalah pengembangan hutan tanaman khususnya jenis penghasil kayu pertukangan lebih besar dibandingkan kayu pulp maupun energi. Pada saat ini rendahnya produksi hutan tanaman dikarenakan teknik silvikultur yang diterapkan kurang tepat. Oleh karena itu perlu dilakukan penelitian diantaranya jenis-jenis meranti merah.

Khusus di Kalimantan, salah satu jenis tanaman yang dapat dikembangkan dan dikelola adalah Kenuar (Shorea johorensis). Jenis ini merupakan jenis andalan yang banyak diminati orang dan menjadi primadona di pasar Eropa Barat karena batangnya lurus dan kayunya mulus (tak ada penyakit busuk hati). Pertumbuhan jenis ini termasuk cepat, pada umur 4,5 tahun ratarata riap diameter dapat mencapai 1,8 - 1,9 cm/th di Hak Pengusahaan Hutan (HPH) Sari Bumi Kusuma (SBK), Kalimantan Tengah (Suparna \& Purnomo, 2004).

Untuk menunjang program pembangunan hutan tanaman dengan jenis kenuar telah dilakukan penanaman di areal penelitian pada lahan yang telah terbakar pada tahun 1982 dan 1997 dengan berbagai macam perlakuan pemeliharaan. Pemeliharaan tanaman muda sangat penting untuk pertumbuhan tanaman, disamping untuk mengurangi persaingan terhadap tanaman pokok dalam pengambilan unsur hara di dalam tanah, juga memberikan ruang atau masuknya cahaya yang dibutuhkan oleh tanaman.

Penelitian ini bertujuan untuk mengetahui perlakuan pemeliharaan yang baik dan efektif terhadap pertumbuhan kenuar. Diharapkan dari hasil penelitian dapat diperoleh informasi tentang teknik penanaman meranti pada areal bekas kebakaran khususnya di hutan penelitian Balai Penelitian Teknologi Perbenihan Samboja.

\section{METODOLOGI}

\section{A. Lokasi dan Waktu}

Penanaman telah dilakukan pada areal hutan belukar bekas kebakaran di areal penelitian Balai Penelitian Teknologi Perbenihan Samboja. Secara administratif pemerintahan termasuk Kelurahan Sei Merdeka, Kecamatan Samboja, Kabupaten Kutai 
Kartanegara. Waktu penelitian dimulai bulan November 2004 sampai dengan bulan November 2006.

\section{B. Tanah dan Iklim}

Jenis tanah di lokasi penelitian adalah Podsolik Merah Kuning pada umumnya memiliki $\mathrm{pH}$ yang rendah, lapisan topsoil tipis dan miskin unsur hara terutama fosfor $(\mathrm{P})$. Berdasarkan klasifikasi iklim Schmidt dan Ferguson (1951) termasuk tipe iklim A dengan rata-rata curah hujan tahunan berkisar antara $1.6822 .314 \mathrm{~mm}$ dan hari hujan $72-154$ hari. Ketinggian tempatnya antara 40 - $150 \mathrm{~m}$ dari permukaan laut.

\section{Metoda}

Untuk pembuatan petak coba dilakukan penyiapan lahan seluas 2,5 hektar. Bahan yang digunakan adalah bibit berasal dari cabutan yang diambil dari areal HPH PT. INHUTANI I Berau pada bulan Desember Tahun 2003, kemudian dipelihara di persemaian Balai Penelitian Teknologi Perbenihan Samboja. Kegiatan penyiapan lahan sendiri meliputi penanaman dengan berbagai jarak tanam, pembuatan lubang tanam, dan pemasangan ajir, kemudian dilakukan penanaman.

Penanaman dilakukan dengan sistem jalur dengan lebar jalur 1,5 m, dengan perlakuan jarak tanam $7 \mathrm{~m} \times 7 \mathrm{~m} ; 5 \mathrm{~m} \times 5 \mathrm{~m}$ dan $3 \mathrm{~m} \times 3 \mathrm{~m}$. Setelah 3 bulan ditanam dilakukan penyulaman, selanjutnya setelah enam bulan ditanam dilakukan perlakuan pemeliharaan serta pengukuran tinggi dan diameter sebagai pengukuran awal. Untuk pengukuran diameter dilakukan \pm dua $\mathrm{cm}$ di atas permukaan tanah dengan alat sigmat (kaliper) dan pengukuran tinggi dilakukan dari permukaan tanah hingga pucuk tertinggi dengan menggunakan meteran.

Pemeliharaan pertama dilakukan pada enam bulan setelah penanaman dengan empat macam perlakuan pemeliharaan pada masing-masing plot adalah:

1. Kontrol (tanpa dipelihara).

2. Penyiangan jalur tanam (horizontal), yaitu perlakuan pemeliharaan dengan membersihkan seluruh tumbuhan bawah sepanjang jalur.

3. Pembebasan (vertikal), yaitu perlakuan pemeliharaan dengan membersihkan seluruh tumbuhan atas sepanjang jalur. Untuk tumbuhan yang berdiameter besar (10 $\mathrm{cm}$ ke atas) dan sulit untuk ditebang, dimatikan dengan peracunan menggunakan Roundup (merk dagang), yaitu herbisida dengan senyawa aktif glifosat dalam formula garam isopropil amin dengan konsentrasi $10 \%$ dalam air, yang disemprot dengan botol plastik volume 500 $\mathrm{ml}$, melalui bacokan kapak ke dalam pohon (kayu gubal) secara melingkar batang pada ketinggian selutut pekerja.

4. Kombinasi (penyiangan dan pembebasan), yaitu perlakuan pemeliharaan dengan membersihkan seluruh tumbuhan baik tumbuhan bawah maupun atas.

\section{Rancangan Percobaan}

Rancangan percobaan yang digunakan adalah split plot dengan jarak tanam ( $3 \mathrm{~m} \times 3 \mathrm{~m} ; 5 \mathrm{~m} \times 5 \mathrm{~m}$ dan $7 \mathrm{~m} \times 7 \mathrm{~m}$ ) sebagai plot utama dan perlakuan pemeliharaan (horizontal, vertikal dan kombinasi dan kontrol) sebagai sub plot dengan ulangan sebanyak tiga kali. Luasan petak coba berukuran $\pm 50 \mathrm{~m} \times 50 \mathrm{~m}( \pm 0.25 \mathrm{ha})$. Jadi jumlah petak coba yang dibuat sebanyak sembilan petak coba. Jumlah bibit yang diperlukan untuk penanaman dan penyulaman pada sembilan petak coba sebanyak 1.426 bibit. 


\section{E. Analisa Data}

Data yang dikumpulkan adalah persen hidup, pertumbuhan diameter dan tinggi setelah 18 bulan pemeliharaan di lapangan. Analisa data dilakukan dengan analisa varian (ANOVA) dengan Uji F. Apabila terdapat perbedaan yang nyata maka dilakukan uji lanjutan dengan uji lanjut Beda Nyata Terkecil (BNT).

\section{HASIL DAN PEMBAHASAN}

\section{A. Persen Hidup}

Hasil pengamatan terhadap persen hidup tanaman kenuar setelah 18 bulan pemeliharaan menunjukkan rata-rata persen hidup berkisar dari 33,33\% s/d 92,86\%. Ratarata persen hidup tanaman untuk tiap perlakuan disajikan pada Gambar 1.

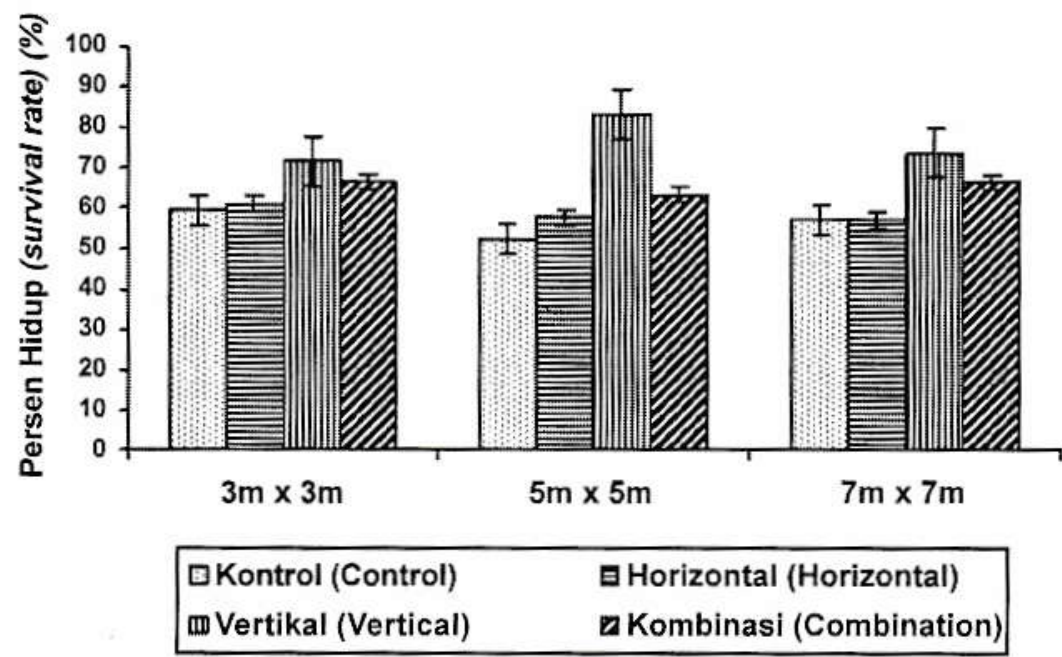

Gambar(Figure) 1. Rata-rata persen hidup tanaman kenuar setelah 18 bulan ditanam di lapangan (Average of survival rate of kenuar after 18 months cultivated in the field).

Berdasarkan hasil analisis keragaman (Lampiran 1) kelompok, jarak tanam dan interaksi jarak tanam dan pemeliharaan tidak menunjukkan pengaruh yang nyata terhadap persen hidup. Perlakuan pemeliharaan memberikan pengaruh sangat nyata terhadap persen hidup. Untuk melihat perlakuan pemeliharaan yang paling baik dilakukan uji lanjut BNT seperti disajikan pada Tabel 1.

Tabel(Table) 1. Hasil uji lanjut BNT terhadap persen hidup tanaman kenuar setelah 18 bulan ditanam di lapangan (Results of LSD test for survival rate of kenuar after 18 months cultivated in the field)

\begin{tabular}{|l|c|}
\hline Perlakuan (Treatment) & Persen hidup (Survival rate) (\%) \\
\hline Horizontal (Horizontal) & $56,25 \mathrm{a}$ \\
\hline Kontrol (Control) & $58,62 \mathrm{a}$ \\
\hline Kombinasi (Combination) & $65,56 \mathrm{a}$ \\
\hline Vertikal (Vertical) & $76,34 \mathrm{~b}$ \\
\hline
\end{tabular}

Keterangan (Remarks): Angka-angka yang diikuti oleh huruf yang sama tidak menunjukkan perbedaan yang nyata (Values followed by the same letters are not significantly different) 
Dari hasil uji lanjut $\mathrm{BNT}$ dengan nilai $\mathrm{BNT}_{\mathrm{p}(0,05)}$ sebesar 4,477 menunjukkan bahwa persen hidup yang paling besar adalah pada perlakuan pemeliharaan vertikal dibandingkan perlakuan pemeliharaan lainnya, dengan rata-rata persen hidup sebesar $76,34 \%$.

Perlakuan jarak tanam belum memberikan pengaruh yang nyata terhadap persen hidup tanaman kenuar. Hal ini disebabkan karena tanaman tanaman kenuar tergolong muda (tingkat pancang), sehingga perlakuan jarak tanam yang diberikan belum memberikan persaingan antar tanaman baik persaingan akar maupun tajuk. Persaingan akan terjadi bila tajuk tanaman saling bersentuhan dan persaingan dalam memperoleh cahaya matahari serta unsur hara. Pada kondisi yang demikian diharapkan pengaruh perlakuan jarak tanam akan terlihat.

Perlakuan pemeliharaan menunjukkan pengaruh nyata pada persen hidup dan yang paling baik terlihat pada perlakuan pemeliharaan vertikal. Pada pemeliharaan vertikal dilakukan pembersihan yang menaungi tanaman kenuar. Pembersihan ini akan memberikan ruang bagi masuknya cahaya yang sangat dibutuhkan oleh tanaman untuk melangsungkan proses fotosintesis. Hasil fotosintesis ini sangat berguna bagi tanaman dalam bertahan hidup.

\section{B. Pertumbuhan Tinggi}

Dari hasil pengukuran tinggi diperoleh rata-rata pertumbuhan tinggi tanaman kenuar setelah 18 bulan pemeliharaan berkisar dari $18,10 \mathrm{~cm} \mathrm{~s} / \mathrm{d} 91,84 \mathrm{~cm}$. Rata-rata pertumbuhan tinggi tanaman kenuar untuk tiap perlakuan disajikan pada Gambar 2.

Berdasarkan hasil analisis keragaman (Lampiran 2) kelompok, jarak tanam dan interaksi antar perlakuan tidak menunjukkan pengaruh yang nyata terhadap pertumbuhan tinggi. Akan tetapi perlakuan pemeliharaan memberikan pengaruh sangat nyata terhadap pertumbuhan tinggi. Dari hasil uji lanjut $B N T$ dengan nilai $\mathrm{BNT}_{\mathrm{p}(0,05)}$ sebesar 7,208 menunjukkan bahwa pertumbuhan tinggi yang paling besar adalah pada perlakuan pemeliharaan vertikal dibandingkan perlakuan pemeliharaan lainnya, dengan rata-rata pertumbuhan tinggi sebesar $62,04 \mathrm{~cm}$ seperti terlihat pada Tabel 2 .

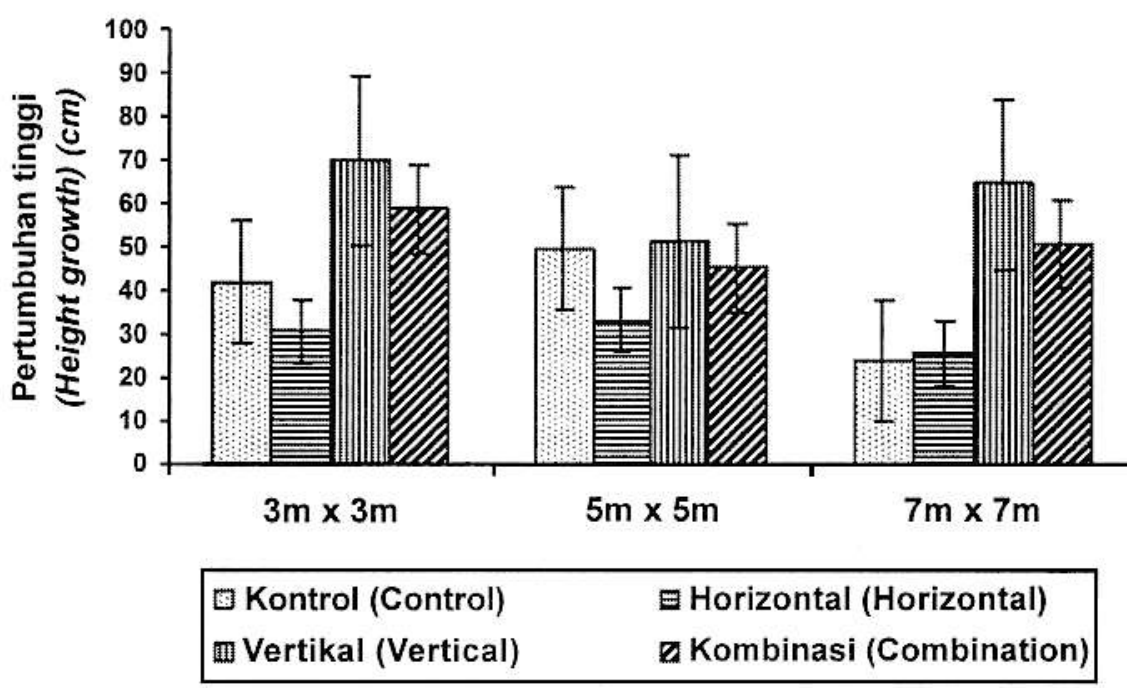

Gambar(Figure)2. Rata-rata pertumbuhan tinggi tanaman kenuar setelah 18 bulan ditanam di lapangan (Average of height growth of kenuar after 18 months cultivated in the field) 


\begin{tabular}{|l|c|}
\hline Perlakuan (Treatment) & Pertumbuhan Tinggi (Height growth) $(\mathrm{cm})$ \\
\hline Horizontal (Horizontal) & $29,97 \mathrm{a}$ \\
\hline Kontrol (Control) & $38,64 \mathrm{~b}$ \\
\hline Kombinasi (Combination) & $51,70 \mathrm{c}$ \\
\hline Vertikal (Vertical) & $62,04 \mathrm{~d}$ \\
\hline
\end{tabular}

Keterangan (Remarks): Angka-angka yang diikuti oleh huruf yang sama tidak menunjukkan perbedaan yang nyata (Values followed by the same letters are not significantly different)

Seperti pada persen hidup, perlakuan jarak tanam belum memberikan pengaruh yang nyata terhadap pertumbuhan tinggi tanaman kenuar. Hal ini disebabkan karena belum terjadi persaingan antar tanaman baik persaingan akar dalam memperoleh makanan maupun persaingan tajuk dalam memperoleh cahaya.

Berdasarkan uji di atas (Tabel2) perlakuan pemeliharaan vertikal menunjukkan pengaruh nyata pada pertumbuhan tinggi. Pemeliharaan vertikal dimaksudkan adalah pembebesan pohon yang menaungi tanaman kenuar, sehingga akan memberikan ruang bagi masuknya cahaya yang sangat dibutuhkan oleh tanaman. Cahaya digunakan oleh tanaman untuk proses fotosintesis. Hasil fotosintesis ini sangat berguna bagi pertumbuhan tanaman untuk membuat makanan yang penting untuk pertumbuhan. Semakin baik proses fotosintesis semakin baik pula pertumbuhan tanaman. Zipperlen \& Press (1996) menyatakan bahwa tingkat pertumbuhan dan fotosintesis pada Shorea leprosula dan Dryobalanops lanceolata meningkat pada lingkungan dengan ketersediaan cahaya yang lebih baik.

\section{C.Pertumbuhan Diameter}

Dari hasil pengukuran diameter diperoleh rata-rata pertumbuhan diameter tanaman kenuar setelah 18 bulan pemeliharaan berkisar dari $0,30 \mathrm{~cm} \mathrm{~s} / \mathrm{d} 1,09 \mathrm{~cm}$. Rata-rata pertumbuhan diameter tanaman kenuar untuk tiap perlakuan disajikan pada Gambar 3 .

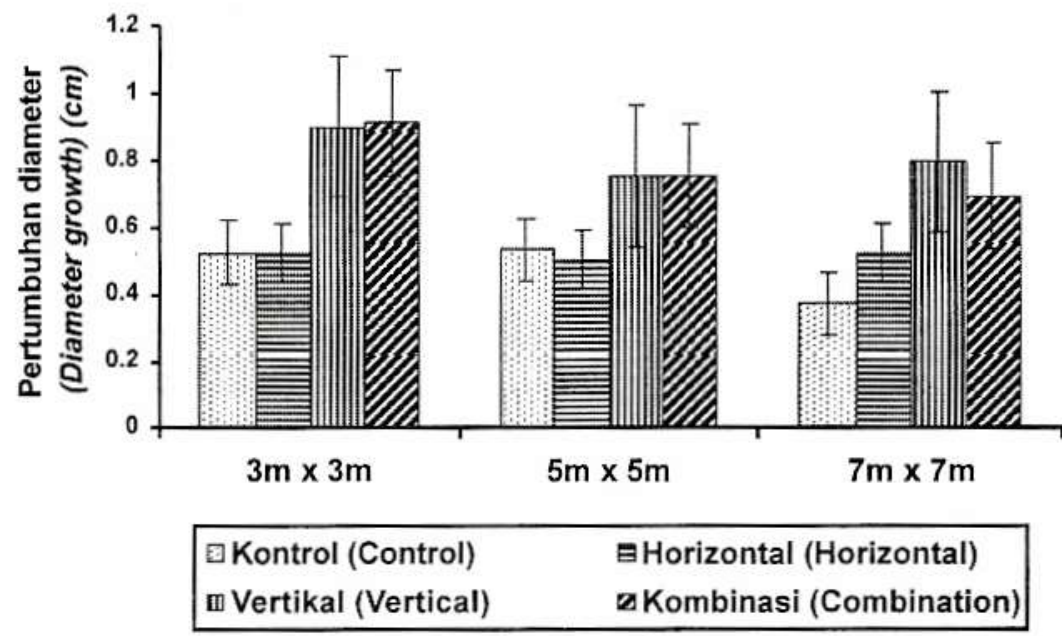

Gambar(Figure) 3. Rata-rata pertumbuhan diameter tanaman kenuar setelah 18 bulan ditanam di lapangan (Average of diameter growth of kenuar after 18 months cultivated in the field)

Hasil analisis keragaman (Lampiran 3) yang dilakukan menunjukkan bahwa kelompok, jarak tanam dan interaksi antar perlakuan tidak menunjukkan pengaruh yang nyata terhadap pertumbuhan diameter. Seperti pada pertumbuhan tinggi, perlakuan pemeliharaan juga memberikan pengaruh sangat nyata terhadap pertumbuhan diameter. 
Berdasarkan hasil uji lanjut BNT dengan nilai $\mathrm{BNT}_{\mathrm{p}(0.05)}$ sebesar 0,106 menunjukkan bahwa pertumbuhan diameter yang paling besar adalah pada perlakuan pemeliharaan vertikal dibandingkan perlakuan pemeliharaan lainnya, dengan rata-rata pertumbuhan diameter sebesar $0,81 \mathrm{~cm}$ seperti terlihat pada Tabel 3 .

Tabel(Table)3. Hasil uji lanjut BNT terhadap pertumbuhan diameter tanaman kenuar setelah 18 bulan ditanam di lapangan (Results of LSD test for diameter growth of kenuar after 18 months cultivated in the field)

\begin{tabular}{|l|c|}
\hline Perlakuan (Treatment) & Pertumbuhan Diameter (Diameter growth) $(\mathrm{cm})$ \\
\hline \hline Kontrol (Control) & $0,47 \mathrm{a}$ \\
\hline Horizontal (Horizontal) & $0,51 \mathrm{a}$ \\
\hline Kombinasi (Combination) & $0,78 \mathrm{~b}$ \\
\hline Vertikal (Vertical) & $0,81 \mathrm{~b}$ \\
\hline
\end{tabular}

Keterangan (Remarks): Angka-angka yang diikuti oleh huruf yang sama tidak menunjukkan perbedaan yang nyata (Values followed by the same letters are not significantly different)

Perlakuan pemeliharaan vertikal memberikan pengaruh nyata pada pertumbuhan diameter. Pemeliharaan vertikal telah memberikan intensitas cahaya yang masuk lebih banyak dibandingkan pada perlakuan kontrol maupun pemeliharaan horizontal, sehingga pertumbuhan tanaman baik tinggi maupun diameter menjadi lebih baik.

Disamping itu, intensitas cahaya yang tinggi juga akan memacu perkembangan mikroba tanah, terutama cendawan jenis mikoriza. Effendi et al. (1996) menyatakan bahwa jenis-jenis dipterokarpa sangat bergantung pada mikoriza dalam perolehan nutrisinya. Tanaman kenuar merupakan salah satu jenis dipterokarpa, sehingga untuk dapat hidup dengan baik sangat memerlukan kehadiran mikoriza. Hubungan akar tanaman dengan mikoriza bersifat simbiosis mutualisme (Colpaert \& Van Tichelen, 1994) yaitu jamur mikoriza menerima persenyawaan karbon yang tidak kompleks dari akar tanaman dan mengisap air dan zat hara dari tanah kemudian mengangkutnya ke akar pohon. Keberadaan mikoriza pada akar tanaman sangat menguntungkan, karena dapat meningkatkan kemampuan tanaman untuk menyerap unsur hara terutama phosphor dan perbaikan struktur tanah (De la Cruz, 1982).

Seperti diketahui bahwa areal untuk penanaman tanaman kenuar adalah bekas hutan yang terbakar pada tahun 1982 dan 1997 dan menjadi hutan belukar. Pada hutan yang bekas terbakar pada umumnya mikroba tanahnya berkurang terutama jenis mikoriza. Pembukaan naungan dengan pemeliharaan vertikal akan memberikan ruang bagi cahaya untuk mencapai permukaan tanah dan memacu perkembangan mikoriza.

Untuk perkembangan cendawan mikoriza juga dipengaruhi oleh suhu tanah. Smits et al. (1988) menyatakan bahwa cendawan yang hidup bersama akar dalam simbiose ektomikoriza sangat peka terhadap suhu tanah yang tinggi. Hasil penelitian Smits et al. (1988) menunjukkan bahwa pada suhu tanah di atas $30^{\circ} \mathrm{C}$ sudah terlihat pengaruh negatif bagi perkembangan ektomikoriza.

Pada pemeliharaan vertikal, hanya tumbuhan penaung yang dibebaskan, sehingga menyebabkan cahaya yang masuk lebih banyak. Hal ini baik untuk pertumbuhan tanaman tanaman kenuar dan perkembangan cendawan mikoriza. 
Untuk pengamatan selanjutnya terhadap pertumbuhan tanaman kenuar ini masih terus dilakukan, dan diharapkan pada tahun-tahun berikutnya pengaruh jarak tanam akan memberikan pengaruh terhadap pertumbuhan tanaman kenuar, sehingga dapat diketahui perlakuan jarak tanam yang mana akan memberikan pertumbuhan yang optimal.

\section{KESIMPULAN}

Pemeliharaan vertikal tanaman kenuar pada lahan hutan belukar bekas terbakar telah memberikan peningkatan persen hidup, pertumbuhan tinggi dan pertumbuhan diameter masingmasing sebesar $76,34 \%, 62,04 \mathrm{~cm}$ dan $0,81 \mathrm{~cm}$. Diharapkan perlakuan pemeliharaan vertikal yang dilakukan setiap enam bulan sekali dapat meningkatkan pertumbuhan tanaman kenuar terutama pada hutan belukar bekas terbakar di Kalimantan Timur.

\section{DAFTAR PUSTAKA}

Badan Planologi Kehutanan. 2006. Indikasi Kawasan Hutan dan Lahan Yang Perlu Dilakukan Rehabilitasi. Jakarta: Departemen Kehutanan, Badan Planologi Kehutanan.

Colpaert, J.V. and K.K. Van Tichelen. 1994. Mycorrhizas and Environmental Stress. Fungi and Environmental change. Symposium of The British Mycological Society Held at Cranfield University. Cambridge University Press.

De la Cruz, R.E. 1982. Micorrhizae in Forestry. In Training Course on biological Aspects of Silviculture. BIOTROP. Bogor.

Direktorat Produksi Hasil Hutan. 2000. Peninjauan Penerapan Sistim Silvikultur pada areal Pengusahaan Hutan Alam Produksi dalam Lokakarya Pembangunan Pembahasan Sistim Silvikultur Sesuai Karakteristik Unit KPHP dalam rangka Strategi Pengelolaan Hutan Alam Produksi. 25 Januari 2000, Jakarta.

FWI/GFW] 2001. Potret Keadaan Hutan Indonesia. Forest Watch Indonesia dan Washington DC. Bogor: Global Forest Watch.

Effendi, R.,A. Saridan., R. Munro., K. Ingleby and R. Scott. 1996. Impact of Forest Clearance on Growth and Micorrhizal Infection of Natural Generating Dipterocarp Seedling. Buletin Penelitian Kehutanan Vo. 9 No. 2; 10-22. BPK Samarinda.

Forestry Working Group. 2002. Matrix of action of Forestry Working Group as the Follow up to CGI Quaterly Review Meeting 20 February 2002. Ministry of Forestry, Jakarta (Tidak ditebitkan).

Schmidt and Ferguson. 1951. Rainfall types based on dry and wet period ratios for Indonesia with Western New Guinea. Verhandelingen No. 42. Jawatan Meteorologi dan Geofisika. Jakarta.

Smits, W., D. Leppe dan M. Noor. 1988. Metode Inokulasi untuk Persemaian Dipterocarpaceae. Asosiasi Panel Kayu Indonesia. Samarinda.

Suparna, N dan Purnomo. 2004. Pengalaman Membangun Hutan Tanaman Meranti Di PT Sari Bumi Kusuma Kalimantan Tengah. Seminar Nasional dalam rangka 70 tahun Prof. Dr Ir Soekotjo dengan tema Visi Silvikultur Indonesia menyongsong Kehutanan 2045, Yogyakarta, 4-5 Maret 2004.

Sutisna, M. 2006. Kondisi Hutan Alam di Kaltim dan Upaya Peningkatan Produktivitas Melalui Pembuatan Hutan Tanaman. Seminar Alih teknologi Pembuatan Bibit Tanaman Sistim Fog-Colling (KOFFCO). Kerjasama antara Balai Penelitian dan Pengembangan Kehutanan Kalimantan dengan Komatsu-Jica. Tanggal 18-19 Juli 2006 di Samarinda.

Zipperlen, S.W. and M.C. Press. 1996. Photosyntesis in relation to growth and seedling ecology of two dipterocarp rain forest tree species. Jurnal of Ecology No. $84: 863876$. 